\title{
ESENSI SERTA EKSISTENSI BARONG DAN RANGDA (Eksplorasi Teologi Hindu)
}

\author{
I Made Ari Susandi \\ Program Studi Brahma Widya \\ Universitas Hindu Negeri I Gusti Bagus Sugriwa Denpasar \\ Email: ari_susandi77@yahoo.com
}

\begin{abstract}
The dynamics of Balinese life are constantly under the spotlight because of the variety of cultural activities that blend with various aspects of life. The arts of barong and rangda are spread across all districts and cities in Bali, but not all pakraman villages or temples have barong and rangda arts. This is due to the existence of barong and rangda in the religious dynamics of Balinese Hindu society. although in reality barong and rangda are not merely a form of art, but furthermore they are the implementation of theology (divine teachings) of Hinduism, both regarding the philosophical side (the essence) of religion and psychology (psychological/emotional aspects) of religion. This article is the result of qualitative research by applying the theological description approach and philosophy of art. The existence of Barong-Rangda is very important in the socio-religious life of Balinese people, because people still need symbols to express their devotion to God/Ida Sang Hyang Widhi Wasa.
\end{abstract}

Keywords: Essence, Existence, Barong, Rangda.

\begin{abstract}
ABSTRAK
Dinamika kehidupan masyarakat Bali tiada henti-hentinya mendapat sorotan karena beragam rupa aktivitas budaya yang menyatu dengan berbagai sendi kehidupan. Kesenian barong dan rangda tersebar di seluruh kabupaten dan kota di Bali, tetapi tidak semua desa pakraman ataupun pura memiliki kesenian barong dan rangda. Hal ini disebabkan keberadaan barong dan rangda dalam dinamika religius masyarakat Hindu Bali. meskipun pada kenytaannya barong dan rangda tidak semata-mata sebagai sebuah wujud kesenian, tetapi lebih jauh lagi ia merupakan implementasi teologi (ajaran ketuhanan) dari agama Hindu, baik menyangkut sisi filosofis (hakikat) keagamaan maupun psikologi (aspek kejiwaan/emosi) keagamaan. Artikel ini merupakan hasil penelitian kualitatif dengan menerapkan metode pendekatan deskripsi teologis dan filsafat seni. Eksistensi BarongRangda sangat penting dalam kehidupan sosio-religius masyarakat Bali, karena masyarakat masih memerlukan simbol untuk mengekspresikan bhaktinya kehadapan Tuhan/Ida Sang Hyang Widhi Wasa.
\end{abstract}

Kata Kunci: Esensi, Eksistensi, Barong, Rangda.

\section{PENDAHULUAN}

Agama Hindu yang dikenal sekarang memiliki tiga kerangka dasar agama Hindu yakni; tattwa (filsafat, nilai, pandangan), susila (aktifitas, tindakan), dan acara (upakara dan 
upacara). Sedangakn kebudayaan juga dibangun menjadi tiga wujud budaya yakni ide (gagasan, nilai), aktifitas (tindakan, dan prilaku), serta artepek (material). Jika dikaitkan agama Hindu dan kebudayaan tentu jelas terlihat benang merahnya jika dilihat hubungannya seperti filsafat dengan idea, susila dengan aktifitas, dan acara dengan upakara dan upacara. Kaitan antara agama dan kebudayaan memang sangat erat, dengan meminjam uraian Koentjaraningrat (2009: 1-2) bahwa agama atau religi merupakan salah satu bagian dari budaya atau dapat juga dikatakan religi tersebut adalah salah satu dari unsur budaya.

Dinamika kehidupan masyarakat Bali tiada henti-hentinya mendapat sorotan karena beragam rupa aktivitas budaya yang menyatu dengan berbagai sendi kehidupan. Masyarakat Bali yang sejak dahulu dikenal sebagai masyarakat religius. Karena itu sesungguhnya ketika berbicara tentang budaya Bali yang dimaksud adalah Budaya Agama Hindu di Bali. Sebab budaya Bali tidak seperti sekarang ini jika tidak ditopang oleh ajaran agama Hindu. Jadi kebudayaan Bali adalah wujud Agama Hindu di Bali. Sehingga agama dan kebudayaan di Bali seperti selembar mata uang yang memiliki dua sisi atau muka. Aktivitas budaya tersebut merupakan suatu ekspresi jiwa manusia Bali sebagai bentuk responnya terhadap alam lingkungan tempat hidupnya maupun sebagai bentuk respon terhadap pengalaman hidupnya.

Oleh sebab itu, di setiap daerah khususnya di Bali memiliki kekhasan budaya sesuai dengan potensi alam maupun potensi SDM masing-masing daerah bersangkutan. Dari berbagai rupa aktivitas budaya masyarakat Bali tersebut, salah satu di antaranya adalah aktivitas berkesenian baik yang bersifat sakral maupun profan yang terdiri dari seni tari, seni rupa, seni lukis, seni suara, seni musik, seni sastra, dan sebagainya. Diantara banyak ragam kesenian yang ditemukan di Bali terdapat kesenian barong dan rangda, baik yang bersifat sakral maupun profan yang keberadaannya tersebar di beberapa desa di Bali.

Kesenian barong dan rangda tersebar di seluruh kabupaten dan kota di Bali, tetapi tidak semua desa pakraman ataupun pura memiliki kesenian barong dan rangda. Hal ini disebabkan keberadaan barong dan rangda dalam dinamika religius masyarakat Hindu Bali terdapat berbagai alasan mengapa suatu pura masyarakatnya nyungsung tapakan barongrangda, sementara di pura yang lain tidak ditemukan tapakan ini.

Setiap tapakan barong-rangda di sebuah pura selanjutnya pada kesempatan-kesempatan tertentu dipentaskan sebagai kesenian sakral. Itu juga alasannya mengapa barong dan rangda disebutkan sebagai aktivitas berkesenian (budaya), meskipun pada kenytaannya barong dan rangda tidak semata-mata sebagai sebuah wujud kesenian, tetapi lebih jauh lagi ia merupakan implementasi teologi (ajaran ketuhanan) dari agama Hindu, baik menyangkut sisi filosofis (hakikat) keagamaan maupun psikologi (aspek kejiwaan/emosi) keagamaan. Aspek teologis dari barong dan rangda inilah yang akan dibahas dalam artikel ini.

\section{KAJIAN PUSTAKA \\ 2.1 Pengertian Barong}

Apabila istilah Barong dipasangkan dengan Rangda (Barong-Rangda), maka dipastikan yang dimaksudkan Barong tersebut jenis Barong Ket. Hal ini perlu dipertegas mengingat terdapat berbagai bentuk dan jenis Barong, tetapi hanya jenis Barong Ket yang lazim berpasangan dengan Rangda yang sekaligus pasangan ini (Barong-Rangda) kemudian mewakili aspek teologis (ajaran ketuhanan) keagamaan. Sementara itu berbagai bentuk Barong lainnya sering ditemukan difungsikan secara mandiri, baik sebagai sarana berkesenian maupun sebagai simbol keagamaan pada sebuah pura. Oleh karena itu BarongRangda sulit diberikan arti dan makna yang bersifat objektif yang mampu mewakili gambaran objek tersebut. Adapun beberapa arti tentang Barong dan Rangda diantaranya sebagai berikut. 
Pertama, Gautama dan Sariani (2009:58) menyebutkan Barong sebagai perwujudan binatang mitologis lambing kebenaran untuk melawan kekuatan yang merusak. Banyak macam-macam Barong, seperti; Bangkal, berbentuk babi jantan besar; Barong Bangkung, berbentuk induk babi; Barong Ket/ keket/kekek, Barong dengan bentuk binatang mitologis sebagai perwujudan "Banaspati Raja." Barong landung yang berbentuk manusia tinggi besar (berbeda dari Barong yang lain), yang lakilaki disebut Jero Gede dengan muka hitam yang menyeramkan, sedangkan yang wanita disebut Jero Luh dengan muka berwarna putih atau kuning agak lucu.

Kedua, Segara (2000: 9) menyebutkan secara etimologi (asal kata), kata Barong berasal dari bahasa Sanskerta, yaitu kata " $b(h)$ arwang" yang di dalam bahasa Melayu atau bahasa Indonesia sejajar dengan kata Beruang, yaitu nama seekor binatang yang hidup di daerah Asia, Amerika, dan Eropa, berbulu hitam dan tebal serta ekornya pendek.

Ketiga, Titib (2000:418) menyebutkan kata Barong berasal dari kata "barwang (Barong)" dalam bahasa Jawa Kuno berarti beruang, beruang madu (Ursus Malayanus). Kata Sanskerta untuk beruang adalah "Baluka", sedangkan kata "bharwa" yang diduga menjadi kata barwang berarti yang memakan dengan baik, seperti lembu.

Memperhatikan beberapa pengertian di atas semuanya memiliki kelemahan masingmasing. Misalnya dengan menyebut Barong sebagai binatang mitologis, namun kenyataannya terdapat jenis Barong Landung yang berwujud manusia menyeramkan. Demikian pula apabila Barong disepadankan dengan binatang beruang, maka jenis binatang ini tidak ada disebutkan pernah muncul di Bali. Dengan demikian kalau aktivitas budaya merupakan ekspresi untuk merespon alam sekitar, maka bilamana Barong dikatakan sebagai perwujudan beruang, maka boleh jadi kesenian Barong tidak merupakan hasil olah budaya asli Bali, tetapi adopsi dari luar. Demikian juga halnya binatang beruang tidak tergolong ke dalam binatang suci dalam Hindu seperti halnya Garuda, Sapi, Merak, Naga, Angsa, dan sebagainya. Dengan demikian definisi tersebut dapat dikatakan kurang mewadahi hakikat Barong sebagai khasanah kebudayaan asli Bali yang dijiwai agama Hindu Bali.

Sesuai dengan bentuk dan wujudnya, Barong di Bali memiliki bentuk atau jenis yang berpariasi antara Barong yang satu dengan barong yang lainya sesuai dengan kreativitas dan proses imajinasi dalam menciptakan berbagai corak dan gaya seni. Adapun jenisjenis Barong yang terdapat di Bali yaitu:

1. Barong Ket, sering juga disebut Barong ket-ket, Barong Rentet, atau Barong Ketet. Jenis Barong ini merupakan penggambaran dari Banaspati Raja yang berarti pelindung hutan atau pohon-pohonan (raja hutan). Bentuknya merupakan kombinasi dari Singa, Macan, Sapi atau beruang yang memiliki kekuatan magis. Jenis Barong ini hampir terdapat disemua desa adat di Bali, biasanya disertai dengan Rangda sebagai pendampingnya (Titib, 2003: 418).

2. Barong Bangkal, merupakan Barong yang menyerupai babi yang telah berumur tua dan dianggap sebagai binatang mitos yang mengingatkan cerita kelahiran Bhoma. Ketika Brahma dan Visnu masing-masing menunjukkan kehebatannya, muncul Siwa dalam wujud lingga kristal ujung atasnya menembus langit dan pangkal bawahnya masuk kedalam bumi. Brahma mencari ujung atasnya dalam wujud burung layanglayang dan Wisnu mencari pangkalnya dengan berubah wujud menjadi seekor babi yang buas. Barong ini biasanya "ngelawang" (datang kerumah-rumah penduduk) untuk menari sebagai pengusir kekuatan jahat dalam rangkaian hari raya Galungan dan Kuningan (Titib, 2003: 419).

3. Barong Asu. Kata asu merupakan bahasa bali halus dari kata anjing. Secara leksikal Asu berarti anjing. Wajah Barong ini mempunyai kepala anjing. Barong ini merupakan 
Barong yang angker dan disakralkan. Biasanya digunakan untuk "ngelawang" dalam rangkaian hari raya Galungan dan Kuningan (Titib, 2003:419).

4. Barong Macan. Barong dengan wajah atau tapel-nya berwujud kepala harimau. Barong Macan ini dikaitkan dengan ceritra tantri, kulitnya dibuat dari kain beludru loreng menyerupai bulu macan yang asli. Dipentaskan pada waktu acara ngelawang dalam rangkaian hari raya Galungan dan Kuningan (Titib, 2003: 419).

5. Barong Gajah. Barong ini berwujud seekor gajah yeng merupakan binatang yang terkenal di India, juga merupakan binatang mitos yang suci. Dipertunjukkan dalam rangkaian hari raya Galungan dan Kuningan (Titib, 2003: 420).

6. Barong Sampi. Berwujud seekor sapi jantan, dipentaskan pada waktu acara ngelawang dalam rangkaian hari raya Galungan dan Kuningan (Titib, 2003:420).

7. Barong Singa. Terdapat di Kabupaten Buleleng, fungsinya sama dengan BarongBarong yang lain, sebagai penolak bala bencana (Titib, 2003: 420).

8. Barong Landung. Barong ini tidak berwujud binatang, melainkan berwujud laki-laki dan perempuan. Kata landung dalam bahasa Bali berarti tinggi, Karena wujud dari Barong ini baik yang laki-laki maupun yang perempuan semuanya tinggi-tinggi, dimainkan seperti ondel-ondel Betawi. Barong Ladung seperti Barong-Barong lainnya sangat disakralkan oleh umat penyungsungnya. Tidak hanya sepasang laki-laki dengan taringnya yang melengkung keluar yang disebut Jero Gede dan perempuan yang berwarna putih (wajahnya mirip putri china) yang disebut Jero Luh, tetapi juga diikuti oleh beberapa pengiring sebagai putra dan putrinya. Kadang-kadang dipentaskan dalam rangkaian hari raya Galungan dan Kuningan (Titib, 2003:420).

9. Barong Brutuk, Barong ini terdapat di Desa Trunyan, Kintamani Bangli. Tapel dari Barong ini menyerupai raksasa yang merupakan perwujudan dewa Ratu pancering jagat dan Dewi Ayu pingit dengan bala pengiringnya. Penari Barong ini adalah lakilaki yang ketika pementasan memakai senjata cemeti dari lidi tanpa diiringi gamelan. Puncak pertunjukan Barong ini adalah bertemunya Ratu Pancering Jagat dengan Dewa Ayu Pingit yang dilambangkan bertemunya Brutuk laki-laki dengan Brutuk Perempuan. Tujuan dari pementasan Barong ini adalah untuk memohon kesuburan (Titib, 2003: 421).

10. Barong Blas-blasan. Barong ini disebut juga Barong Kedingkling atau Nongkling mengingatkan suara gamelan yang ditabuh. Barong Blas-blasan adalah Barong dengan topeng-topeng para tokoh dalam cerita Ramayana (wayang Wong), diiringi gamelan batel, bebarongan. Barong ini dipentaskan ngelawang. Penarinya sebagian besar anak-anak, sedang penabuhnya orang-orang dewasa (Titib, 2003: 421).

11. Barong Gagombrangan. Jenis Barong ini sudah jarang dapat disaksikan. Kata Gombrang artinya rambutan terurai. Mungkin sejenis Barong Mamedi di beberapa desa di Bali (Titib, 2003: 421).

12. Barong sae. Barong berwajah macan atau kelelawar. Barong ini rupanya karena pengaruh budaya Cina (Titib, 2003: 421).

13. Barong Jaran. Wajah Barong ini menyerupai Kuda (Titib, 2003: 421).

14. Barong Menjangan. Wajah Barong ini seperti rusa atau menjangan (Titib, 2003: 422).

15. Barong Dawang-Dawang. Merupakan variasi dari Barong Landung di daerah Tabanan, topengya berwujud raksasa dan sangat besar (Team Survey ASTI,1997: 117). Di Desa Muncan, Kabupaten Karangasem, Dawang-Dawang (untuk yang laki-laki) dan Dudong (untuk yang perempuan) digunakan sebagai pelengkap upacara ngaben, yakni mengiringi wadah (usungan jenasah) ke setra (kuburan), bersama dengan 'patungan' berupa singa, gajahmina atau lembu hitam, Di Denpasar, tidak terdapat DawangDawang melainkan Ogoh-Ogoh yang diusung oleh masyarakat sebagai perwujudan 
roh yang meninggal. Dalam perkembangan mutakhir, Ogoh-Ogoh dikaitkan dengan perayaan Nyepi berbentuk Bhuta, Kala dan Raksasa (Titib, 2003: 422).

Berdasarkan pengertian serta berbagai jenis bentuk barong yang telah dipaparkan tersebut, adapun Barong yang dimaksudkan dalam artikel ini adalah suatu bentuk perwujudan atau sosok Banaspati Raja, yaitu wujud binatang gaib dengan kekuatan magis sebagai penjelmaan Dewa Siwa saat menghancurkan berbagai penyakit dan marabahaya. Dengan demikian, pengertian Barong disini adalah lebih kepada pengertian filosofis (tattwa Hindu) yang ada dalam teks-teks lontar yang menjelaskan tentang Barong dan Rangda. Demikian pula, Barong bukan lagi dipahami sebagai "binatang beruang" tetapi binatang gaib yang diwujudkan oleh tetua kita seperti apa yang kita lihat sekarang. Binatang gaib, tentunya memiliki kelebihan-kelebihan yang digambarkan dalam bentuk menyeramkan dan dipercaya memiliki kekuatan-kekuatan yang luar biasa (magis) sehingga masyarakat Bali meyakini sosoknya sebagai yang sakral (tenget). Ini merupakan konstruksi teologi lokal yang berupaya untuk memastikan apa yang diyakini adalah terkait dengan keyakinan terhadap Tuhan. Tuhan selalu baik dan selalu mampu mengalahkan kejahatan. Keyakinan itu diwujudkan dalam pertunjukkan atau pementasan sifat-sifat baik melawan sifat-sifat buruk yang digmabrkan sebagai Barong dan Rangda.

\subsection{Pengertian Rangda}

Gautama dan Sariani dalam Wirawan (2019:425) menyebutkan Rangda memiliki arti: (1) janda; (2) peran dalam cerita Calonarang sebagai janda tukang sihir dari girah dengan mengenakan topeng yang menyeramkan, mata besar melotot, taring besar- besar, rambut putih terurai lidah panjang, serta kuku panjang. Hal ini dipertegas oleh Segara (2000:20) yang menyebutkan istilah Rangda adalah bahasa Bali alus untuk penyebutan janda dari kalangan Tri Wangsa di Bali (Brahmana, Ksatrya, Wesya), sedangkan janda dari kalangan Sudra Wangsa dikenal dengan sebutan balu/walu.

Wirawan (2019:420) menyatakan bahwa rangda biasanya tidak saja dibedakan atas dasar bentuk wajah topengnya, melainkan dibedakan dari warna topeng. Sedikitnya terdapat dua jenis Rangda yang dibedakan atas warnanya, yaitu Ratu Ayu untuk topeng Rangda dengan cat putih, dan Ratu Mas dengan cat topeng berwarna merah. Tidak di setiap desa Rangda ratu Ayu dan Ratu Mas ini berpasangan, dimana adakalanya ha-nya terdapat Rangda Ratu Ayu saja yang berpasangan dengan Barong, demikian juga hanya terdapat Rangda Ratu Mas saja juga bersanding dengan Barong. Sedangkan dari segi bentuknya Rangda sulit dibedakan karena semuan-ya mirip, hanya saja pembedaan tersebut didasarkan atas gaya topeng oleh seniman pembuatnya atau style pemahatnya. Untuk kategori bentuk, topeng Rangda dibedakan: (a) Bentuk Nyinga, yaitu topeng dengan sedikit menonjol ke depan menyerupai singa. Ekspresi topeng style ini biasanya harus berkesan galak dan buas; (b) Bentuk Nyleme, yaitu apabila bentuk topeng Rangda ini dengan wa-jah menyerupai wajah manusia, melebar dan tidak terlalu menonjol. Ekspresi yang ditampilkan oleh topeng bentuk ini adalah ketenangan, angker berwibawa; (c) Bentuk Raksasa, bentuk ini yang penting menyeramkan sebagaimana bayangan orang tentang raksasa yang menakutkan, dan umumnya topeng Rangda bentuk ini yang banyak terdapat di masyarakat. Selanjutnya ada gaya atau pakem Rangda yang berbedabeda di masing-masing daerah tergantung pada desa, kala, patra dan mewacara.

Oleh sebab itu dalam artikel ini istilah Rangda yang dimaksud adalah perwujudan Dewi Durga di bumi bergelar Hyang Bherawi dengan ciri-ciri wajah seram menakutkan, rambut terurai panjang, mata melotot, lidah menjulur panjang, dan kuku panjang. Definisi tersebut lebih dapat mewakili kehadiran Rangda dalam fungsinya sebagai peranti keagamaan maupun sebagai peranti kesenian. Kehadiran Barong dan Rangda dalam kehidupan keagamaan Hindu di Bali walaupun dianggap oleh sebagian orang sebagai kepercayaan- 
kepercayaan yang bersifat mitos, tetapi orang tidak boleh melupakan bahwa dalam Hindu mitos dihadirkan dalam kerangka metodologis untuk menjangkau yang tidak terjangkau.

\section{METODE}

Metode pada sebuah karya ilmiah memegang peranan penting guna mendapatkan data yang objektif, valid dan selanjutnya digunakan untuk memecahkan permasalahan yang telah dirumuskan. Hasil tulisan dalam artikel ini merupakan hasil penelitian kualitatif dengan menerapkan metode pendekatan deskripsi teologis dan filsafat seni. Connolly dalam Wirawan (2019:418) menjelaskan bahwasanya pendekatan teologi memfokuskan pada sejumlah konsep, khususnya didasarkan pada ide theos-logos, studi atau pengetahuan tentang Tuhan.

Terkait dengan metode kualitatif data dikumpulkan melalui teknik studi literatur dan internet searching. Studi literatur adalah serangkaian kegiatan yang berkenaan dengan metode pengumpulan data pustaka, membaca dan mencatat, serta mengelolah bahan penelitian. Menurut Danial dan Warsiah (2009:80), Studi Literatur adalah merupakan penelitian yang dilakukan oleh peneliti dengan mengumpulkan sejumlah buku buku, majalah yang berkaitan dengan masalah dan tujuan penelitian. Teknik ini dilakukan dengan tujuan untuk mengungkapkan berbagai teori-teori yang relevan dengan permasalahan yang sedang dihadapi/diteliti sebagai bahan rujukan dalam pembahasan hasil penelitian.

Data yang terkumpul selanjutnya melakukan proses analisis data seperti pilah-memilah data, klasifikasai data dan kodifikasi data. Sugiyono (2007:337), mengemukakan bahwa aktivitas dalam menganalisa data kualitatif dilakukan secara interaktif dan berlangsung secara terus menerus sampai tuntas. Tahap analisis selanjutnya setelah reduksi data adalah penyajian data. Penyajian data adalah menyajikan sekumpulan informasi yang tersusun yang memberikan kemungkinan adanya penarikan kesimpulan.

\section{PEMBAHASAN}

Aspek Teologi dalam Barong dan Rangda

Histrorikal pembuatan bentuk barong maupun rangda terjadi karena pertimbanganpertimbangan empiris (nyata), yaitu hal-hal yang bersifat rasional dan indrawi, maupun karena alasan yang bersifat intuitif, yaitu berhubungan dengan keyakinan magis keagamaan. Terlebih lagi di dalam Hinduisme terutama yang menempuh jalan bhakti sangat tergantung pada media pemujaan Tuhan melalui media simbol suci. Simbol dibutuhkan oleh manusia bhakti untuk menghubungkan dirinya dengan Tuhan yang tidak terpikirkan.

Selaras dengan teori interaksionisme simbolik yang berangkat dari pemikiran bahwa realitas sosial merupakan sebuah proses yang dinamis. Individu-individu berinteraksi melalui simbol, yang maknanya dihasilkan dari proses negosiasi yang terus-menerus oleh mereka yang terlibat dengan kepentingan masing-masing. Makna suatu simbol bersifat dinamis dan variatif, tergantung pada perkembangan dan kepentingan individu, yang dibingkai oleh ruang dan waktu. Seperti yang telah disebutkan sebelumnya, individu diletakkan sebagai pelaku aktif, sehingga konsep mengenai diri (self) menjadi penting. Konsep diri yang dikaitkan dengan emosi, nilai, keyakinan, dan kebiasaan-kebiasaan, serta pertimbangan masa lalu dan masa depan, turut mempengaruhi diri dalam pengambilan peran. (Abdulah dalam Laksmi, 2017:124)

Oleh karena itu untuk mencapai kepuasan mental spiritual dalam aktivitas bhakti mutlak diperlukan sarana atau media sebagai jembatan penghubung antara pemuja dengan Yang Dipuja (Tuhan). Di samping itu media pemujaan akan dibuat seindah mungkin 
sehingga sering dipersepsikan kalau aktivitas keagamaan Hindu di Bali adalah aktivitas kesenian semata yang tidak berpijak pada teologi (ajaran Ketuhanan) yang jelas.

Sesungguhnya tidaklah demikian, sebab Agama Hindu berlandasan pada Satyam, Siwam, Sundaram. Satyam adalah prinsip kebenaran yang bersumber pada sastra suci, kemudian Siwam adalah kesucian, dan Sundaram adalah keharmonisan. Berdasarkan tiga prinsip tersebut, bahwa spiritual dibangun atas pengukuhan nilai-nilai kebenaran dalam hidup untuk mencapai kesucian, dan hanya dalam hidup yang suci akan tercipta keharmonisan lahir bathin. Keharmonisan adalah puncak pencapaian spiritual, jiwa yang seimbang yang mengekspresikan keindahan (manoharam) memancar keluar.

Dengan demikian unsur keindahan dalam pemujaan Hindu bukanlah sarana, melainkan sebuah pencapaian yang dihasilkan oleh aktivitas bhakti. Oleh karena itu para pemuja yang murni melihat segala sesuatunya sebagai sesuatu yang indah, karunia Tuhan tanpa tepi (tampaking kuntul angalayang ring segara tan petepi). Atas alasan itu pula peranti keagamaan termasuk Barong dan Rangda tidak memiliki bentuk fisik yang baku, tetapi disesuaikan dengan ekspresi keindahan yang muncul dari tiap jiwa-jiwa pemuja yang berkehendak mempersembahkan karyanya semata-mata atas alasan bhakti. Itu pula alasannya mengapa di Bali dikenal beberapa bentuk Barong dan Rangda.

Sebagai sebuah pratima atau simbol suci keagamaan, Barong dan Rangda di Bali dijadikan sthana ista dewata melalui upacara ngerehang. Setelah manifestasi Siwa dan Sakti bersthana pada Barong dan Rangda yang diundang lewat upacara tersebut, kedua pralingga Ida Bhatara tersebut seterusnya akan ditempatkan (kalinggihang) di pura. Sementara itu bagi masyarakat umum atau umat Hindu sebagai pengempon pura tersebut selanjutnya akan bhakti (sujud bhakti) Barong dan Rangda.

Sehingga, pensthanaan Barong dan Rangda tersebut menjadi media peningkatan bhakti atau upaya menghubungkan diri dengan Ida Sang Hyang Widhi Wasa melalui mesedhana atau. Barong dan Rangda hubungannya dengan konsep bhakti adalah sebagai objek pemusatan pikiran (Myarpitamanobudhi). Objek untuk memusatkan pikiran sangat diperlukan dalam melakukan pemujaan. Bayangkan saja, ke pura melakukan pamuspan tetapi tidak ada Barong-Rangda atau arca lainnya maka pikiran tidak akan terpusat.

Oleh karena itu citra atau simbol suci diperlukan yang dalam hal ini adalah petapakan Barong dan Rangda. Kehadiran media suci Barong dan Rangda yang mataksu diantaranya menunjukkan kekuatan gaib di dalamnya akan mempermudah hati tunduk atau yakin terhadap kehadiran dewata yang dekat dengan diri pemuja. Ketundukan hati memunculkan peningkatan sraddha, dan sraddha yang kuat akan membangkitkan bhakti dalam diri. Sraddha akan memunculkan bhakti, yaitu ketika keimanan seseorang mantap terhadap sesuatu maka akan memunculkan rasa bhakti.

Dalam keagamaan keimanan kepada Tuhan yang mantap akan menjadikan seseorang bhakti terhadap yang diimaninya. Oleh sebab itu, baik sraddha maupun bhakti bukanlah sesuatu yang bisa dimiliki secara tiba-tiba, melainkan harus dilatih secara terus menerus, terutama melatih rasa. Demikian pula, mengimani Barong-Rangda tidak saja dating secara tiba-tiba melainkan harus melewati proses. Terkadang dewasa ini banyak damuh Bhatara yang mengabaikan sebuah proses, sehingga kejadian seperti Rangda "metebek", Rangda "tembus" sering terjadi. Terlebih mereka yang mengutamakan intelektual, rasio dan sejenisnya maka akan mengabaikan sebuah proses.

Tetapi Barong dan Rangda akan dapat mengolah intelek terutama di bidang pengetahuan ketuhanan, sehingga sangat membantu memunculkan, menumbuhkan, dan meneguhkan sikap sraddha dan bhakti, tetapi itu saja belum cukup. Pengetahuan ketuhanan (tattwa) yang baik akan menghasilkan kualitas sraddha dan bhakti yang baik dan kuat bilamana diuji dalam pengalaman langsung, dan pengalaman hanya bisa diperoleh dengan 
cara mempraktikkan ajaran-ajaran tattwa (filsafat ketuhanan), sila (meneladani perilaku orang-orang suci dan arif bijaksana).

Pada saat pengetahuan intelek bertemu atau mendapat pembuktian dalam medan pengalaman, ketika itulah seseorang mengalami kepuasan rohani atau kepuasan spiritual disebut atmanastuti. Sraddha pertama-tama dapat dipelajari dengan intelek dengan memehami Brahmawidya atau teologi. Namun keimanan tersebut baru akan hidup setelah melibatkan rasa (emosi) keagamaan dalam diri, dan selanjutkan terimplementasi dalam tindakan sehari-hari (Karsa) sebagai suluh hidup. Masalah Sraddha yang kurang mantap telah menimbulkan berbagai problema dalam kehidupan sehari-hari. Sebagai contoh, karena keimanannya kurang kuat kepada Tuhan maka sering berbagai kesulitan kehidupan yang dialami disangka bersumber dari gangguan ilmu hitam (gangguan leak), terkena kutukan dewata (keduken Bhatara Hyang Guru), terkena gangguan gamang-tonyo, dan sebagainya.

Akibat pemahaman dan keimanan yang bermasalah tersebut akhirnya tidak jarang sebuah keluarga semakin tidak harmonis, saling tuduh dan curiga karena dianggap biang peneror ilmu hitam. Dalam situasi demikian, Sraddha dan Bhakti kepada Ida Sang Hyang Widhi semakin menipis, dan karena kebingungan (orang yang tanpa keyakinan kuat mudah bingung, goyah, dan dibujuk rayu, serta dihasut), orang-orang yang bernasib malang ini akan lari dari satu balian ke balian lainnya untuk meminta pertolongan atas nasib buruk yang menimpanya, tetapi bilamana belum bertemu orang yang arif bijaksana dalam menangani masalah- masalah seperti ini, maka bukan solusi yang akan didapat melainkan akan terjadi komplikasi masalah.

Bagi masyarakat Bali, Barong dan Rangda digolongkan pratima atau bisa juga bisa disebut arca. Istilah Arca untuk simbol dewata di Bali memang kurang populer lagi, tetapi lebih sering disebut pratima namun fungsi maupun dasar teologinya sama dengan Arca. Pemujaan melalui arca dibenarkan dalam Hindu, apalagi Barong dan Rangda tersebut dibuat melalui etika spiritual dengan ketat.

Masyarakat Bali sudah sangat lumrah melaksanakan pemujaan kepada Bhatara Siwa melalui Barong-Rangda yang ditandai dengan melayani kaki Padma Tuhan dengan menghaturkan tirtha (toya anyar) untuk membasuh kaki Beliau sebagai wujud kecintaan dan bhakti terhadap junjungan. Tentu Ida Sang Hyang Widhi yang Nirguna Brahman tidak memiliki kaki, tetapi Tuhan yang sudah mengambil suatu identitas (Saguna Brahman) memiliki kaki sebagaimana halnya manusia.

Setiap persembahyangan seperti pujawali di pura selalu disertai menghaturkan toya anyar untuk persembahan membersihkan kaki dewata, dan setelah dipersembahkan secara simbolik dengan memercikkan air ke pelinggih tempat sthana ista dewata, maka tirtha tersebut kemudian dimohon dan dinamai Tirtha Wangsuh Pada, artinya air cucian kaki Ida Bhatara. Tirtha ini diyakini sangat berkarunia sehingga akan dipercikkan kepada seluruh umat yang hadir mengikuti persembahyangan untuk menyucikan diri masing-masing.

Sebagai sebuah arca (pratima) Barong dan Rangda yang tersimpan di gedong simpen dalam pura tentu tidak memiliki kaki, karena kakinya baru tampak apabila ditarikan oleh juru pundut masing-masing. Untuk itu apabila umat Hindu hendak padasevanam pada kaki Barong dan Rangda dapat dilakukan secara mental yaitu menghaturkan air (toya anyar) ke hadapannya kemudian dipersembahkan dan dipercikkan dengan ke arah Barong dan Rangda dengan niat membersihkan kaki Beliau. Untuk menambah keyakinan kadangkadang tirtha tersebut disentuhkan pada rawis (jenggot) Barong untuk memohon anugerah. Meskipun demikian tirtha tersebut tetap akan disebut Tirtha Wangsuh Pada. 


\section{SIMPULAN}

Berdasarkan atas uraian tersebut di atas, dapat disimpulkan bahwasanya eksistensi Barong-Rangda sangat penting dalam kehidupan sosio-religius masyarakat Bali, karena masyarakat masih memerlukan simbol untuk mengekspresikan bhaktinya kehadapan Tuhan/Ida Sang Hyang Widhi Wasa. Barong dan Rangda akan dapat mengolah intelek terutama di bidang pengetahuan ketuhanan, sehingga sangat membantu memunculkan, menumbuhkan, dan meneguhkan sikap sraddha dan bhakti, tetapi itu saja belum cukup. Pengetahuan ketuhanan (tattwa) yang baik akan menghasilkan kualitas sraddha dan bhakti yang baik dan kuat bilamana diuji dalam pengalaman langsung, dan pengalaman hanya bisa diperoleh dengan cara mempraktikkan ajaran-ajaran tattwa (filsafat ketuhanan), sila (meneladani perilaku orang-orang suci dan arif bijaksana).

\section{DAFTAR PUSTAKA}

Danial dan Wasriah. (2009). Metode Penulisan Karya Ilmiah. Bandung: Laboratorium Pendidikan Kewarganegaraan UPI.

Koentjaraningrat. 2009. Pengantar Ilmu Antropologi. Jakarta: Rineka Cipta.

Kutha Ratna, Nyoman, 2007. Estetika Sastra dan Budaya. Yogyakarta: Pustaka Pelajar.

Laksmi. 2017. Teori Interaksionisme Simbolik dalam Kajian Ilmu Perpustakaan dan Informasi. PUSTABIBLIA: Journal of Library and Information Science, 1(1), 121 138. Tersedia Online dalam: https://ijtihad.iainsalatiga.ac.id/index.php/pustabiblia/article/view/953.

Pendit, Nyoman S. 1991. Bhagavadgita. TT: Yayasan Dharma Sarathi.

Sarwono.2005. Teori Teori Psikologi Sosial. Jakarta: PT.Radja Grafindo Perkasa. Segara, Nyoman Yoga., 2000. Barong dan Rangda. Surabaya: Paramita.

Sugiyono. 2007. Metode Penelitian Kuantitatif, Kualitatif Dan R\&D. Bandung: Alfabeta. Titib, I Made, 1996. Veda Sabda Suci Pedoman Praktis Kehidupan. Surabaya: Paramita. Titib, I Made, 2000. Teologi \& Simbol dalam Agama Hindu. Surabaya: Paramita. Titib, I Made. 2003. Teologi \& Simbol-Simbol dalam Agama Hindu. Surabaya: Paramita. Wirawan, Komang Indra. 2019. Liturgi Sakralisasi Barong-Rangda: Eksplorasi TeoFilosofis Estetik Mistik Bali. MUDRA: Jurnal Seni Budaya, 34(3), 417-427. 